\title{
Diffuse normolipaemic plane xanthoma in a patient with monoclonal gammopathy
}

\author{
Sónia Raquel Mendes, Ana Rita Gameiro, Inês Coutinho, José Carlos Cardoso
}

Dermatology Department,

Coimbra University Hospital, Coimbra, Portugal

Correspondence to Dr Sónia Raquel Mendes; soniaraquel23@gmail.com

Accepted 17 June 2021

\section{DESCRIPTION}

A 70-year-old female Caucasian patient presented with a 7 year-history of extensive yellow papules and macules scattered over the trunk and upper limbs, with mild pruritus (figure 1).

No other body areas were involved, and she did not have other relevant skin lesions.

The patient had no history of previous infectious diseases, of trauma in the last months or any recently started medicines.

Subsequent investigation led to the diagnosis of diffuse plane xanthoma associated with monoclonal gammopathy of undetermined significance.

The diagnosis of diffuse plane xanthoma was confirmed histologically by the presence of clusters of foamy histiocytes, with perivascular and interstitial distribution in the superficial and middle dermis (figure 2).

She carried out a laboratorial workup that revealed a monoclonal IgG lambda gammopathy and is currently being followed in haematology by monoclonal gammopathy of undetermined significance.

Further workup did not reveal any significant abnormalities, namely dyslipidaemia.

Laser treatment was offered but declined by the patient.

Diffuse normolipaemic plane xanthoma (DNPX), which was first described by Altman and Winkelmann, is a rare acquired dermatosis of the subtype of the non-Langerhans histiocytoses group. ${ }^{1-3}$ Clinically, it is characterised by the presence of symmetric flat yellow macular areas or slightly elevated yellow-orange plaques, gradually appear, with a predilection for the eyelids (xanthelasma palpebrarum), neck, upper trunk and flexural folds. ${ }^{1-4}$ DNPX occurs mainly in adults and is associated with normal plasma lipid levels. ${ }^{134}$ Histologically, foam cells (macrophages) and variable numbers of Touton giant cells, lymphocytes and foamy histiocytes are present; sometimes only foam cells can

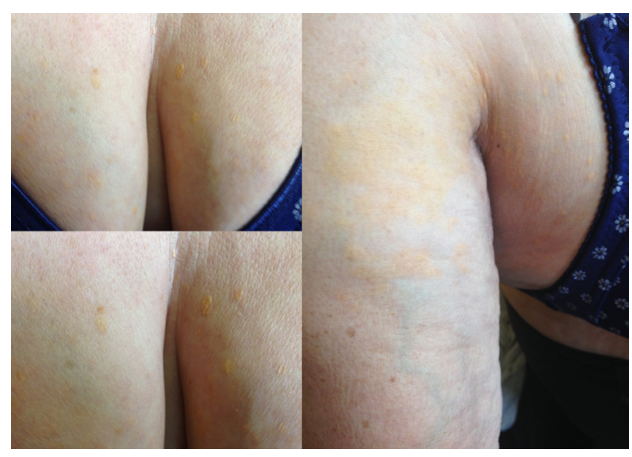

Figure 1 Extensive yellow papules and macules scattered over the trunk and upper limb.

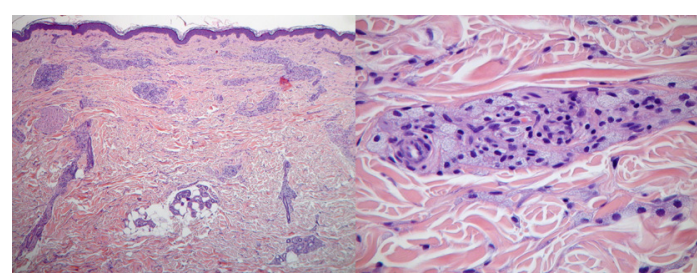

Figure 2 Xantomised histiocyte collections in the superficial and middle dermis $(\mathrm{H} \& \mathrm{E}, \times 40)$, with little inflammatory infiltrate $(H \& E, \times 200)$.

be seen. ${ }^{1}$ The pathogenesis is still unclear, however, in gammopathy-associated DNPX, monoclonal IgG is thought to bind to circulating low-density lipoprotein (LDL), rendering the antibody-LDL complex more susceptible to phagocytosis by macrophages. ${ }^{2}$ Over half of the reported cases of DNPX are associated with lymphoproliferative disorders. ${ }^{2}$ DNPX has been recognised to be associated with haematological diseases, especially with multiple myeloma, monoclonal gammopathy or monoclonal gammopathy of undetermined significance, chronic granulocytic or lymphatic leukaemia, Waldenström's macroglobulinaemia, cryoglobulinaemia and lymphoma. ${ }^{1-5}$ DNPX may precede the onset of these diseases over several years, and clinical and laboratory monitoring is recommended periodically, even for patients who appear to have no underlying condition. ${ }^{23}$ DNPX does not cause significant health problems although the lesions can be cosmetically disfiguring; there are currently several treatment options available. ${ }^{3}$ In patients with limited involvement, individual lesions can be excised. ${ }^{3}$ Other options include chemabrasion, dermabrasion and ablative laser therapy, such as erbium-doped yttrium aluminium garnet (Er:YAG) laser treatment. ${ }^{3}$

\section{Learning points}

- Diffuse normolipaemic plane xanthoma is a rare dermatosis that occurs mainly in adults, and may associated with monoclonal gammopathy.

- This case demonstrates the importance of cutaneous manifestations as a clue of important haematological diseases, which should motivate clinicians to be familiar with this entity.

Contributors SRM (first author): acquisition and analysis of data, planning, conducting, conception and design of the article, as well as revision and final approval. ARG: acquisition of data and final approval. IC: acquisition of data and final approval. JCC: acquisition of data, revision and final approval.

Funding The authors have not declared a specific grant for this research from any funding agency in the public, commercial or not-for-profit sectors. 
Images in...

Competing interests None declared.

Patient consent for publication Obtained.

Provenance and peer review Not commissioned; externally peer reviewed.

\section{REFERENCES}

1 Altman J, Winkelmann RK. Diffuse Normolipemic plane xanthoma. Arch Dermatol 1962;85:633-40.
2 Stockman A, Delanghe J, Geerts M-L, et al. Diffuse plane normolipaemic xanthomatosis in a patient with chronic lymphatic leukaemia and monoclonal gammopathy. Dermatology 2002;204:351-4.

3 Cohen YK, Elpern DJ. Diffuse normolipemic plane xanthoma associated with monoclonal gammopathy. Dermatol Pract Concept 2015;5:65-7.

$4 \mathrm{Kim} \mathrm{KJ}$, Lee DP, Suh HS, et al. Diffuse plane xanthoma in a patient with chronic myeloid leukemia. J Dermatol 2004;31:503-5.

5 Kyle RA, Therneau TM, Rajkumar SV, et al. Prevalence of monoclonal gammopathy of undetermined significance. N Engl J Med 2006;354:1362-9.

Copyright 2021 BMJ Publishing Group. All rights reserved. For permission to reuse any of this content visit

https://www.bmj.com/company/products-services/rights-and-licensing/permissions/

BMJ Case Report Fellows may re-use this article for personal use and teaching without any further permission.

Become a Fellow of BMJ Case Reports today and you can:

- Submit as many cases as you like

- Enjoy fast sympathetic peer review and rapid publication of accepted articles

Access all the published articles

- Re-use any of the published material for personal use and teaching without further permission

\section{Customer Service}

If you have any further queries about your subscription, please contact our customer services team on +44 (0) 2071111105 or via email at support@bmj.com.

Visit casereports.bmj.com for more articles like this and to become a Fellow 